\title{
RELAC̣̃̃ES COM O SABER NA ATIVIDADE DE PRODUC̣ÃO DE DOCUMENTÁRIO CIENTÍFICO NO ENSINO DE BIOLOGIA
}

\author{
HERON OMAR ARRAYA CAZÓN - (https://orcid.org/0000-0002-6751-1142)* \\ Universidade de São Paulo, São Paulo, SP - Brasil \\ ODISSÉA BOAVENTURA DE OLIVEIRA - (https://orcid.org/0000-0002-5775-2081)** \\ Universidade Federal do Paraná, Curitiba, PR - Brasil
}

RESUMO: Busca-se compreender a "Relação com o Saber" na produção de documentários científicos, por alunos do Ensino Médio, na disciplina de Biologia. Analisa-se aqui o documentário "Anomalias cromossômicas: um olhar sobre a Síndrome de Down" visando à mobilização dos alunos: suas relações particulares com o saber, com a ciência, com o mundo, consigo e com os outros. Para isso faz-se uma aproximação entre os referenciais da Análise de Discurso e a Relação com o Saber. Por meio da imagem de um cubo, uma matriz com os eixos $x$ (interdiscurso), $y$ (intradiscurso) e z (relação com o saber), observa-se tal harmonia no percurso de produção, possibilitando correlacionar memória discursiva, relação com o saber e sentidos produzidos.

Palavras-chave: Análise de Discurso; Autoria; Ensino de Biologia.

\section{RELATIONSHIPS TO KNOWLEDGE IN THE PRODUCTION OF SCIENTIFIC DOCUMENTARIES IN BIOLOGY TEACHING}

ABSTRACT: The purpose of this research is to understand the "Relationship to Knowledge" in the production of scientific documentaries made by high school students in biology class. It is analyzed the documentary "Chromosomal abnormalities: a look at the Down Syndrome" aiming the mobilization of students: their particular relationship to knowledge, to science, to the world, to themselves and to others. For this reason, it is made an approach between the references of Discourse Analysis and Relationship to Knowledge. Through the image of a cube, an array with the $\mathrm{x}$ axis (interdiscourse), $\mathrm{y}$ (intradiscourse) and $\mathrm{z}$ (relationship to knowledge), it is observed such harmony in the production route, that enables to correlate discursive memory, relationship to knowledge and produced meaning.

Keywords: Discourse Analysis; Authorship; Biology Teaching.
* Mestre em Educação pela UFPR - Curitiba - PR, Doutorando em Educação na USP - São Paulo.

E-mail:<heroncazon@gmail.com>

* *Doutora em Educação pela USP, Professora nos Programas de Pós Graduação em Educação e Mestrado Profissional em Educação da UFPR, Curitiba - PR. E-mail:< odissea@terra.com.br > 


\section{RELACIONES COM EL SABER EM LA ACTIVIDAD DE PRODUCCIÓN DE DOCUMENTAL CIENTÍFICO EN LA ENSEÑANZA DE BIOLOGÍA}

RESUMEN: Buscamos entender la "Relación con el Saber" en la producción de documentales científicos por los estudiantes de la escuela secundaria en la asignatura de la Biología. Se analiza aquí el documental "Las anomalías cromosómicas: una mirada sobre la Síndrome de Down", teniendo por objetivo la movilización de los estudiantes: sus relaciones particulares con el saber, con la ciencia, con el mundo, con ellos mismos y con los demás. Para esto, fue hecha una conexión entre la referencia del Análisis del Discurso y la Relación con el saber. A través de la imagen de un cubo, una matriz con los ejes $x$ (interdiscurso), $y$ (intradiscurso) y $z$ (relacióncon el saber), se observa tal armonía en la trayectoria de producción que permite correlacionar la memoria discursiva, relación con el saber y los sentidos producidos. Palabras-clave: Análisis del Discurso; Autoría; Enseñanza de la Biología. 


\section{INTRODUÇÃO}

Partimos nessa pesquisa da seguinte questão: quais amplitudes poderiam ser contempladas ao se colocar alunos do ensino médio para produzirem um documentário em aulas de Biologia? Projetávamos a princípio que tal atividade envolveria leitura, entrevista, diálogo, criação, elaboração, produção, apresentação. Mas queríamos mais, então para responder à indagação inicial aliamos teorias, em especial a Análise de Discurso (AD), que nos induziam a pensar na posição em que o aluno é colocado no processo pedagógico. Referencial que também nos alertava para o fato de que "a relação do aluno com o universo simbólico não se dá apenas por uma via - a verbal - ele opera com todas as formas de linguagem na sua relação com o mundo" (ORLANDI, 2008, p. 38). Vindo ao encontro, os conceitos de "Relação com o Saber" e de "Mobilização", desenvolvidos por Charlot (2000), nos auxiliavam a pensar no sentido que o saber tem para o sujeito conferindo-lhe relações de um tipo particular com o mundo, consigo e com os outros.

De posse dessas perspectivas propusemos aos alunos do $3^{\circ}$ ano do Ensino Médio que produzissem documentários sobre o conteúdo estudado, tendo por objetivo analisar nesses documentários, bem como no processo de sua produção, quais relações com o saber, com a ciência, com o mundo, consigo e com os outros seriam manifestadas. Com isso esperávamos contribuir para apontar caminhos para que o aluno pudesse expressar sentimentos, desejos, pensamentos, inseguranças e também conhecimentos científicos.

\section{SITUANDO AS RELAC̣̃̃ES COM O SABER}

Charlot desenvolveu o conceito de "relação com o saber" estudando os jovens das camadas populares. Percebeu que aquele jovem que demonstra ser resistente ou passivo diante dos saberes escolares, muitas vezes, com poucos recursos para realizar as tarefas que envolvem a linguagem, demonstra ser bem interativo nas atividades em grupo ou para produzir letras de rap, por exemplo (CHARLOT, 2001).

Então se o aluno cria letras de rap, demonstrando interesse e desenvoltura, pode escrever uma resenha de algum capítulo do livro de Darwin? É claro que pode, depende de como está engajado nas suas relações com o mundo. O aluno que escreve letras de rap pode fazer esta atividade por prazer, num momento de lazer, mas, também, pode estar inconformado com alguma questão social, política, pessoal etc. Tanto na letra da música quanto na resenha há escrita, embora com significados diferentes para o jovem. Portanto, o que importa é a valorização dos saberes nas relações com o aprender. Mas, que tipo de atividade pode conduzir à aprendizagem?

Charlot (2001, p. 17) destaca que a escola pressupõe o 'Eu epistêmico' (o sujeito do conhecimento racional) como já constituído, à espera de condições didáticas que lhe nutram de saber. Ela não se indaga sobre a constituição do 'Eu epistêmico’ e suas relações com o 'Eu empírico' (o sujeito portador de experiências).

O cerne do problema se situa na passagem do "eu empírico" (eu do cotidiano, do senso comum) para o "eu epistêmico" (eu da razão, do conhecimento científico). 
É importante lembrar, neste caso, que o aluno traz consigo conhecimento adquirido a partir de experiências próprias e únicas, vivências e observações de mundo. Essa bagagem de conhecimento pode ser um ponto de partida muito importante para a construção do eu epistêmico, valorizando o que se aprendeu em outras situações, em contextos pessoais e fazendo destas descobertas a chave para alavancar a construção de uma explicação. A semelhança do eu epistêmico e do empírico está na base da curiosidade, se sustenta a partir deste ponto inicial (CHARLOT, 2001).

$\mathrm{O}$ apoio para fundamentar esta abordagem está em três pilares: mobilização, atividade e sentido. O conceito de mobilização implica a ideia de movimento, "mobilizar é pôr em movimento: mobilizar-se é pôr-se em movimento" (CHARLOT, 2001, p. 54). O autor prefere "mobilização" em detrimento de "motivação", pois a mobilização sugere que o sujeito se mobilize ("de dentro"), ao passo que a motivação reforça o fato de que se é motivado por algo ou por alguém ("de fora"). Como o sujeito entrou nessa atividade intelectual? O "para que?" e o "por quê?" são elementos fundamentais para tentar compreender os motivos da mobilização do sujeito.

Charlot (2000) utiliza o conceito de "atividade" em vez de "prática", pois esta remete à ideia de ação finalizada e contextualizada e aquela acentua a questão dos móbiles, ressaltando que se trata de atividade de um sujeito.

Outro conceito adotado é o de "sentido" o qual "é produzido por estabelecimento de relação, dentro de um sistema, ou nas relações com o mundo ou com os outros" (CHARLOT, 2000, p. 56). Algo pode fazer sentido para o indivíduo sem que ele tome conta disto ou, também, algo pode adquirir sentido, mudar de sentido, perder o sentido, pois o sujeito está em transformação de acordo com sua própria dinâmica e confronto consigo, com o mundo e com os outros.

A relação com o saber está imbricada na questão entre a atividade e o social, implicando em posições, ou seja, "as atividades não são independentes das posições sociais - mas não se reduzem a elas” (CHARLOT, 2000, p. 29), pois também introduz o sujeito em seus móbeis (desejos).

Desta forma, para qualquer sujeito, uma pessoa, um local, um momento, uma relação, uma atividade, ou seja, "um conteúdo de pensamento" é que faz sentido, pois estão imersos nesse emaranhado de relações. Portanto, o que faz sentido é o que significa de outra maneira em detrimento do sentido que carrega juízo de valor, de ser: bom, ruim, positivo, negativo etc.

Deve se levar em conta que o sujeito tem uma história pessoal, em um contexto social partilhado por outros, e, somente, investirá num contexto que para ele represente um espaço de significados. Para o sujeito se colocar na posição de aprender requer, além do "fazer" sentido, a projeção de uma atividade que surte efeito.

Em suma, faz sentido para o aluno algo que lhe desperte e tenha relações com outras coisas que já ocorreram em sua vida, coisas que ele já questionou, refletiu. Portanto, um conceito, uma ideia, uma palavra, faz sentido somente se puder ser relacionada à outra (CHARLOT, 2000). Desse modo, "toda relação com o saber é também relação consigo. Aprender envolve uma relação, ao mesmo tempo, daquele que aprende, e, indissociavelmente, com o que ele aprende e com ele mesmo" e completando, Charlot (2001, p. 27) afirma, "toda relação com o saber é também relação com o outro”. 
Assim, "toda relação com o saber é indissociavelmente singular e social" aprender é um processo único. A relação com o aprender é sempre uma relação única de um sujeito, entretanto, esse sujeito por sua vez, é um sujeito social, e aquilo que ele aprende foi anteriormente produzido por uma atividade fundamentada por relações sociais (CHARLOT, 2001, p. 28).

Todas essas relações implicam em três articulações: a relação epistêmica, a relação identitária e a relação social.

Da perspectiva da relação epistêmica com o saber, tem-se que para aprender é necessário se apoiar em objetos, pessoas, locais através de atividades de apropriação de um saber que ainda não se possui. Portanto, "aprender é passar da não-posse a posse, da identificação do saber virtual à sua apropriação do saber real" (CHARLOT, 2000, p. 68). A relação epistêmica com o saber oscila entre a prática e a teoria, entre o concreto e o abstrato, entre o real e o imaginativo. "Aprender" pode ser "apropriar-se" de um objeto intelectual, como entender uma canção em outro idioma, ou "dominar" uma atividade, como saber ler e escrever, ou "dominar" uma relação com os outros e consigo, ou seja, entrar em um relacionamento, cujo sujeito epistêmico é o afetivo também, possui sentimentos.

Para a relação de identidade com o saber é necessário considerar o sentido produzido no sujeito que aprende levando em consideração sua história, suas expectativas, a imagem que tem de si, a imagem que quer projetar de si no outro. Esse outro pode ser uma pessoa física com quem o sujeito se relaciona ou ainda o outro imaginário que cada um tem dentro de si. Posto isso, o que se evidencia na relação identitária é colocar em evidência a construção de si mesmo.

Por fim, a relação social com o saber deve ser analisada em conjunto com outros fatores, por exemplo, o sistema educacional, o mercado de trabalho, para fornecer elementos para uma melhor compreensão entre a identidade social do sujeito, o significado cultural, histórico e pessoal. Charlot afirma que (2000, p. 73) "essa dimensão social não se acrescenta às dimensões epistêmica e identitária: ela contribui para dar-lhes uma forma particular. O sujeito, não tem, por um lado, uma identidade, por outro, um ser social: esses aspectos são inseparáveis".

Em vista disso, tem-se que o sujeito é indissociavelmente social e único e a educação é um processo de humanização, que se insere num contexto social. A pesquisa sobre a relação com o saber requer um trabalho de observação, de exploração, de identificação, de construção de elementos e de processos que a integra (CHARLOT, 2001). Elementos postos em relação.

\subsection{SITUANDO A RELAC̣ÃO COM A LINGUAGEM}

Para analisar os documentários produzidos pelos alunos utilizamos três eixos: o eixo de dispositivos teóricos da Análise de Discurso, o eixo de interdiscurso (sujeito, história e linguagem) e o eixo da relação com o saber. Para tanto, explicamos a seguir os eixos evocados: interdiscurso e dispositivos teóricos.

A AD coloca a interpretação em questão, buscando compreender como os objetos simbólicos produzem sentidos por meio do dispositivo teórico. Uma parte importante desta análise são os sujeitos que participaram da pesquisa, ou melhor, as condições de produção, que compreendem fundamentalmente os sujeitos e a situação, bem como a memória, ou interdiscurso. Conforme a seguir: 


\begin{abstract}
Memória discursiva: o saber discursivo que torna possível todo dizer e que retorna sob a forma do preconstruído, o já-dito que está na base do dizível, sustentando cada tomada da palavra. O interdiscurso disponibiliza dizeres que afetam o modo como sujeito significa em uma situação discursiva dada. (ORLANDI, 2012, p. 31).
\end{abstract}

Assim, o interdiscurso em suma "é todo o conjunto de formulações feitas e já esquecidas, que determinam o que dizemos. Para que minhas palavras tenham sentido é preciso que elas façam sentido" (ORLANDI, 2012, p. 33). Portanto, o que é evidenciado é a relação do que está sendo dito e o que já foi dito, ou seja, entre o intradiscurso (eixo horizontal, eixo da formulação) e o interdiscurso (eixo vertical, eixo da constituição do sentido, história).

A seguir abordamos os dispositivos teóricos que fazem parte da estrutura de análise. São eles: polissemia, deslocamento, não dito, relação de forças e formações imaginárias.

\title{
1.1.1. Paráfrase e Polissemia
}

Estudar discurso requer o trabalho de delimitar o que nele é diferente e o que é igual. Para a $\mathrm{AD}$, o funcionamento da linguagem se assenta na tensão entre processos parafrásticos e polissêmicos, sendo que no dizer há sempre algo que se mantém (processo parafrástico) relacionado com a memória, com o dizível.

Portanto, a paráfrase supõe formulações distintas de um mesmo dizer, retorna aos mesmos espaços do dito. A paráfrase está mais para o lado da conservação, estabilização, já a polissemia pende para o equívoco, o deslocamento, a ruptura de processos de significação.

A paráfrase e a polissemia são duas forças que trabalham de modo contínuo no dizer, há no dizer uma tensão entre o diferente e o igual, entre o já dito e o que está para se dizer. Desta forma, sujeitos e sentidos estão em movimento, traçando seus percursos e significando (ORLANDI, 2012).

Distingue-se, na AD, a criatividade da produtividade. Fazendo uma analogia da paráfrase no mundo, tem-se que pertence ao processo parafrástico a produtividade, a qual mantém o sujeito em um retorno constante ao mesmo espaço do que já foi dito, criado. Desta forma, há produção da variedade do mesmo.

Por outro lado, o processo polissêmico resulta da criatividade, que rompe com o processo de produção da linguagem, que desloca as regras, que produz movimentos, que atinge, na história e com a língua, os sujeitos e seus sentidos. "Para haver criatividade é preciso um trabalho que ponha em conflito o já produzido e o que vai se instituir. Passagem do irrealizado ao possível, do nãosentido ao sentido" (ORLANDI, 2012, p. 37).

A paráfrase tem sua importância, pois é a matriz do sentido, não há sentido sem repetição, sem algo que sustente o saber discursivo. Da mesma maneira, a polissemia tem seu valor, pois é a fonte da linguagem.

\subsubsection{Incompletude: deslocamento}

Para a AD, "a condição da linguagem é a incompletude". Nada está completo, nem sujeitos, nem sentidos. "Constituem-se e funcionam sob o 
modo do entremeio, da relação, da falta, do movimento" (ORLANDI, 2012, p. 52). Porém, isso não implica que o processo de significação esteja aberto e não seja administrado, muito pelo contrário, é por estar aberto que está sujeito à determinação, à estabilização. No entanto, ocorre deslocamento quando sujeito e sentido se repetem e se deslocam, quando há um deslizamento, outro dizer.

Assim, entre a norma e o jogo, o acaso e a necessidade, no confronto do mundo e da linguagem, entre o concreto e o abstrato, na história e na experiência, "na relação tensa entre o simbólico com o real e o imaginário, o sujeito e o sentido se repetem e se deslocam" (ORLANDI, 2012, p. 52).

\subsubsection{0 dito e o não dito}

No discurso sempre há relação entre o dizer e o não dizer. Por exemplo, se uma pessoa diz que emagreceu alguns quilos, o ouvinte pressupõe que antes a pessoa era mais gorda, portanto, o dito traz consigo o pressuposto, que é o nãodito, mas que está presente.

O interdiscurso e a ideologia são noções que contextualizam o não-dizer, ao se considerar que há sempre no dizer algo implícito, uma informação que está subentendida. Um sujeito pode dizer a palavra "manga", esta pode ter o sentido de um fruto, bem como o sentido de uma parte de um vestuário. Ou ainda dizer "estou com raiva" significa pela sua relação com "estou sem calma". Depende do contexto que o sujeito está inserido (ORLANDI, 2012, p. 82).

\subsubsection{Relação de forças: formações imaginárias}

O que explica a relação de forças é que o lugar de onde o sujeito fala é constitutivo do que ele diz. Por exemplo, se o sujeito fala a partir do lugar de aluno suas palavras significam de modo diferente se falasse do lugar de professor. Há situações em que o sujeito pode incorporar papéis que possuem maior ou menor autoridade sobre os outros, sem que esteja naquele lugar. Há uma distinção entre posição e lugar. $\mathrm{O}$ aluno tem a posição de estudante, mas seu discurso pode ocupar um lugar diferente desse.

Um ponto importante a acrescentar é que esses mecanismos de funcionamento do discurso fazem parte das formações imaginárias, desta forma, "não são os sujeitos físicos nem os seus lugares empíricos como tal, isto é, como estão inscritos na sociedade, e que poderiam ser sociologicamente descritos, que funcionam do discurso, mas suas imagens que resultam de projeções" (ORLANDI, 2012 , p. 40). Sendo que a imagem foi construída através de processos de significação, o que faz com que se ouça, muitas vezes, não o que o outro fala, mas a discursividade que já está em quem está ouvindo.

\subsection{FUNÇÃO-AUTOR}

Aspectos da função-autor são importantes para observar a presença do "eu" nos grupos que participaram da produção dos documentários na escola. Para Orlandi (2012, p. 76): 


\begin{abstract}
Não basta falar para ser autor. A assunção da autoria implica uma inserção do sujeito na cultura, uma posição dele no contexto histórico-social. Aprender a se representar como autor é assumir, diante das instâncias institucionais, esse papel social na sua relação com a linguagem: constituir-se e mostrar-se autor.
\end{abstract}

$\mathrm{Na}$ função-autor, o aluno está sujeito a seguir regras, ser coerente, original, demonstrar conhecimento. Essas exigências buscam tornar o aluno um sujeito visível, deixando inteligíveis suas intenções, objetivos e argumentos. Enquanto autor, responsável por suas ações, o aluno manifesta uma exterioridade fazendo alusão à interioridade, arquitetando sua identidade autoral (ORLANDI, 2012).

Posicionamos os estudantes como produtores de documentários na "funçãoautor" (ORLANDI, 2012, p. 75), aluno-autor. Lembrando que o aluno pode se comprometer a fazer o documentário e apenas executar e entregar a proposta de trabalho, não sendo autor. Pois, estar na função-autor toma outras propriedades, exige a presença de sua identidade, seu discurso precisa apresentar uma unidade.

\title{
2. DOCUMENTÁRIO CIENTÍFICO: RELAC̣ÕES COM O SABER E A LINGUAGEM
}

Em geral, as tentativas de definições sobre o documentário se dão em diferenciá-lo da ficção, por meio de sua relação com o real. Para marcar tal diferença Rezende (2013, p. 16) opta em usar a "virtualidade", isto é "a memória de seus personagens e testemunhas, a sobrevivência do passado no presente, a indeterminação da ação-reação dos indivíduos participantes".

Para Nichols (2012), o documentário se engaja no mundo pela representação. Segundo ele, é oferecido ao público um retrato ou representação de reconhecimento do mundo. Já, Rezende (2013, p. 18) considera que há uma estratégia ao utilizar a noção de representação, pois o documentário não estabelece uma relação neutra, imparcial com a realidade, há interesses determinados, referência que é "sempre parcial, distorcida e problemática".

Trazer essa questão dos interesses dos sujeitos envolvidos no documentário nos faz relacionar ao trabalho da ideologia, ou seja, "produzir evidências, colocando o homem na relação imaginária com suas condições materiais de existência" (ORLANDI, 2012, p. 46). Portanto, "nem a linguagem, nem os sentidos, nem os sujeitos são transparentes: eles têm sua materialidade e se constituem em processos em que a língua, a história e a ideologia concorrem conjuntamente" (ORLANDI, 2012, p. 48).

Com o intuito de explorar essas questões, Rezende (2013, p. 18) considera o documentário "não prioritariamente a partir do resultado de uma obra acabada, mas do ponto de vista do processo criativo que o produz, que descreveremos como um campo de virtualizações e atualizações de questões determinadas, que se dá segundo condições determinadas de produção".

Nesse sentido, o documentário pode ser compreendido "como prática, como processo" (REZENDE, 2013, p. 19). Portanto, seja do início da produção do documentário até sua obra finalizada algo inexistente é criado e a virtualidade toma um formato material e atual. Acreditamos que há aí uma relação muito próxima com as noções de condições de produção e o interdiscurso na AD. Pois, o processo de produção do documentário pressupõe as condições determinadas 
dessa produção ao qual o sujeito está submetido. De modo similar, para a AD, as condições de produção compreendem essencialmente os sujeitos e a situação e, também, a maneira como a memória é acionada.

Desta forma, as condições de produção apresentam dois sentidos: o sentido amplo, que inclui o contexto sócio-histórico, ideológico e, o sentido estrito, que faz menção ao contexto imediato.

Já a relação próxima entre o campo de virtualização e atualização de Rezende, se aproxima do interdiscurso, ou melhor, da memória discursiva como é denominada pela AD.

Tomando outra perspectiva sobre a produção do documentário, Ramos (2013) apresenta uma característica intrínseca ao fazer documentário que está no âmbito da defesa de um ponto de vista ou assunção de determinada interpretação dos fatos, de mesmo modo como um advogado se posicionaria ao fazer a defesa de seu cliente.

De modo geral, para Nichols (2012), os documentários não adotam um grupo fixo de técnicas, formas, estilos, nem versam somente um conjunto de questões, mas externam conjuntos distintos e abordagens alternativas. Alguns elementos não são exclusivos do documentário, no entanto, aparecem com certa frequência, como a câmera na mão, a imagem tremida, a utilização de roteiros não fechados, a improvisação, a encenação, o uso de animações, a entrevista, entre outros.

O recurso de entrevista ou depoimento tem por objetivo apresentar mais amplamente o assunto tratado no documentário, tem a função de juntar relatos, depoimentos diversos sobre o contexto abordado.

Um campo comum entre documentário e ficção é a utilização de personagens que assumem um papel de significado importante. Para Ramos (2013), os personagens são utilizados de modo intenso no documentário. Se os filmes de ficção se utilizam de atores que incorporam personagens, os documentários preferem "trabalhar os próprios corpos que encarnam as personalidades no mundo, ou utiliza-se de pessoas que experimentam de modo próximo o universo mostrado" (RAMOS, 2013, p. 26).

\subsection{CENÁRIO DA PESQUISA}

A pesquisa em questão buscou introduzir os alunos em uma linguagem específica, o documentário científico, na perspectiva de que a produção do documentário exigiria comprometimento, desta forma, os posicionamos na "funçãoautor" (ORLANDI, 2012, p. 75), ou melhor, aluno-autor. Ancorou-se também na mobilização defendida por Charlot (2013). Para isso, a estratégia foi iniciar as atividades em aulas de Biologia conhecendo o desejo do aluno, por meio de um questionário com perguntas do tipo: "O que você quer pesquisar? O que tem mais interesse em saber? O que deseja aprender?". Pois, para o autor, "Prestar atenção à mobilização dos alunos leva a interrogar-se sobre o motor interno do estudo, ou seja, sobre o que faz com que eles invistam no estudo" (CHARLOT, 2013, p. 145).

Para a produção do documentário seguimos as etapas: a) apresentação das características do documentário científico, por meio de imagens e textos, para que todos pudessem se situar no contexto inserido; b) Projeção do documentário "Um Olhar Sobre o Passeio Público”, com participação dos dois autores para um relato 
sobre a produção e esclarecimento de dúvidas e curiosidades por parte dos alunos; c) organização de quatro grupos de alunos para a escolha dos temas; d) pesquisa e redação do roteiro; e) apresentação dos roteiros com esclarecimento de dúvidas sobre os conteúdos envolvidos; e) visita aos locais de filmagem; f) entrevistas com os pesquisadores da área escolhida por cada grupo; g) finalização do documentário junto ao professor de Artes da escola; h) sessão "pipoca" para apresentação dos documentários e relato das dificuldades, dos acertos, das estratégias e dos pontos marcantes. Essas etapas aconteceram ao longo de um semestre letivo e foram acompanhadas e orientadas por um dos autores desse estudo que também mediou o agendamento das entrevistas com os pesquisadores da universidade.

Os pesquisadores entrevistados eram estudantes em fase de conclusão do doutorado na temática dos documentários. O convite para essas entrevistas foi direcionado aos laboratórios de Genética, Bioquímica, Paleontologia e conforme as temáticas os voluntários se apresentaram.

Desse modo, o corpus da pesquisa se constitui por questionários respondidos pelos alunos antes de iniciar a produção dos documentários; nossas anotações sobre todo o processo dessa produção, já que acompanhamos tanto os passos em sala de aula quanto fora dela; um dos documentários dentre os quatro que foram produzidos.

O documentário aqui analisado, intitulado "Anomalias cromossômicas: um olhar sobre a Síndrome de Down” foi selecionado por ser o único que traz entrevistas com pessoas do bairro, além do pesquisador da universidade, assim aponta maior autonomia do grupo em priorizar diferentes pontos de vista sobre a temática.

Resumindo, o documentário de 14 minutos inicia com a pergunta "você sabe o que é um cromossomo?" tendo ao fundo uma imagem deste e na sequência pessoas de profissões diversas (secretária, cabeleireira, doméstica, diarista) aparecem com seus nomes e profissão escritos na tela respondendo à pergunta. Na sequência o narrador (voz em off) dá a definição, o local onde encontra o cromossomo e sua função, sendo que a cada característica citada aparecem imagens indicando-a (exemplo: cor de cabelo, altura, cor dos olhos). Narrador faz outra pergunta "você sabe como ocorre uma síndrome?" e aparecem as mesmas pessoas respondendo. Então aparecem alguns cariogramas ilustrando as respectivas síndromes e na sequência o pesquisador (identificado por escrito) inicia a explicação. Quando ele cita uma síndrome sexual, entra a imagem de um cariograma, ilustrando separadamente os cromossomos masculino e feminino. Segue a pergunta pelo narrador: "Como posso saber que o indivíduo tem uma alteração cromossômica?" Pesquisador responde. Outra pergunta do narrador: "Se você soubesse que está esperando um filho com algum tipo de síndrome como seria sua reação?" As pessoas entrevistadas anteriormente respondem que se apavoraria, ou ficaria louca, desesperada, teria reação normal, faria aborto, então a voz alerta: "as síndromes não são nenhum bicho de sete cabeças" o que falta é conhecimento e destaca sobre proibição do aborto no Brasil e os casos em que é liberado. Daí volta-se para a Síndrome de Down, com uma explicação pelo pesquisador. Aos 9:58 minutos se apresenta a mãe de um menino de 6 anos que é portador da síndrome. Narrador faz perguntas intercaladas pelas respostas 
da mãe: "como foi para você ao saber que seu filho é portador de Síndrome de Down?"; "O seu filho tem acompanhamento de saúde diferenciado?”; "E como é a convivência?"; "Alguma situação de preconceito na rua?". A mãe responde a todas as perguntas de modo bastante realista e mostra uma relação bastante positiva de muito carinho e amor para com o filho e dele com ela. Aos 12:51 minutos fica silêncio e entram fotos do garoto em várias etapas da vida. Aos 13:05 minutos entra um cartaz anunciando "21 de março - Dia internacional da Síndrome de Down". Com esse cartaz ao fundo, narrador finaliza: "As síndromes são causadas pelas mutações cromossômicas e não é porque o indivíduo não tem parte do cromossomo que não vai ter sentimento. Vamos respeitá-los e dar o carinho que eles merecem, até porque eles são seres humanos como nós".

\subsection{ENCAMINHAMENTOS METODOLÓGICOS}

Para a análise do documentário selecionamos alguns trechos que denominaremos de recortes ${ }^{1}$ e também momentos do processo de sua produção que foram anotados por nós, os quais denominaremos de conjunturas ${ }^{2}$. Tais fragmentos foram escolhidos, pois são momentos que mais se denotam as relações com o saber.

$\mathrm{Na}$ análise foi composta uma matriz de três eixos: eixo do interdiscurso (a memória discursiva); eixo do intradiscurso (os dispositivos teóricos); eixo da relação com o saber. Os dois primeiros são derivados da AD. O interdiscurso representa os dizeres já-ditos e abstraídos em um montante de enunciações que, na sua soma, constituem o dizível.

Cada eixo representa as coordenadas de um plano cartesiano: $x$, y e z. Desta forma, o primeiro eixo da matriz. $(x)$ se refere à memória que faz parte desta produção do discurso. É chamada de memória discursiva - aquilo que fala antes, por si, em outra posição - ou seja, "o saber discursivo que torna possível todo dizer e que retorna sob a forma do preconstruído, o já-dito que está na base do dizível, sustentando cada tomada da palavra" (ORLANDI, 2012, p. 31).

São esses dizeres que buscamos compreender, objetos simbólicos produzindo sentidos. Assim, a interpretação se torna uma parte do todo, trabalhando os mecanismos, os limites que fazem parte dos processos de significação. Logo, não existe um "código" de interpretação que procura, no discurso, a verdade enquanto direcionamento e sim há construção de dispositivos teóricos (ORLANDI, 2012).

$O$ segundo eixo da matriz. (y) sustenta os dispositivos teóricos, já detalhados encontrados na análise do documentário, sendo eles: (1) polissemia, (2) Não dito, (3) deslocamento, (4) relação de forças, (5) formações imaginárias.

O terceiro eixo (z), por fim, refere-se à relação com o saber. Reiteramos que o intuito do trabalho está no âmbito da aprendizagem do aluno ao produzir o documentário, resultando em saberes. Buscamos, portanto, compreender os momentos em que o sujeito se aproxima do saber, ou seja, se desenvolve: relação epistêmica, relação pessoal e relação social, conforme explicado anteriormente.

Para uma visualização da análise do documentário com esses conceitos, construímos um cubo com legendas que apresentam as estratificações de cada eixo. 
Figura 1. Representação dos eixos: dispositivos teóricos (y), interdiscurso (x) e relação com o saber (z)

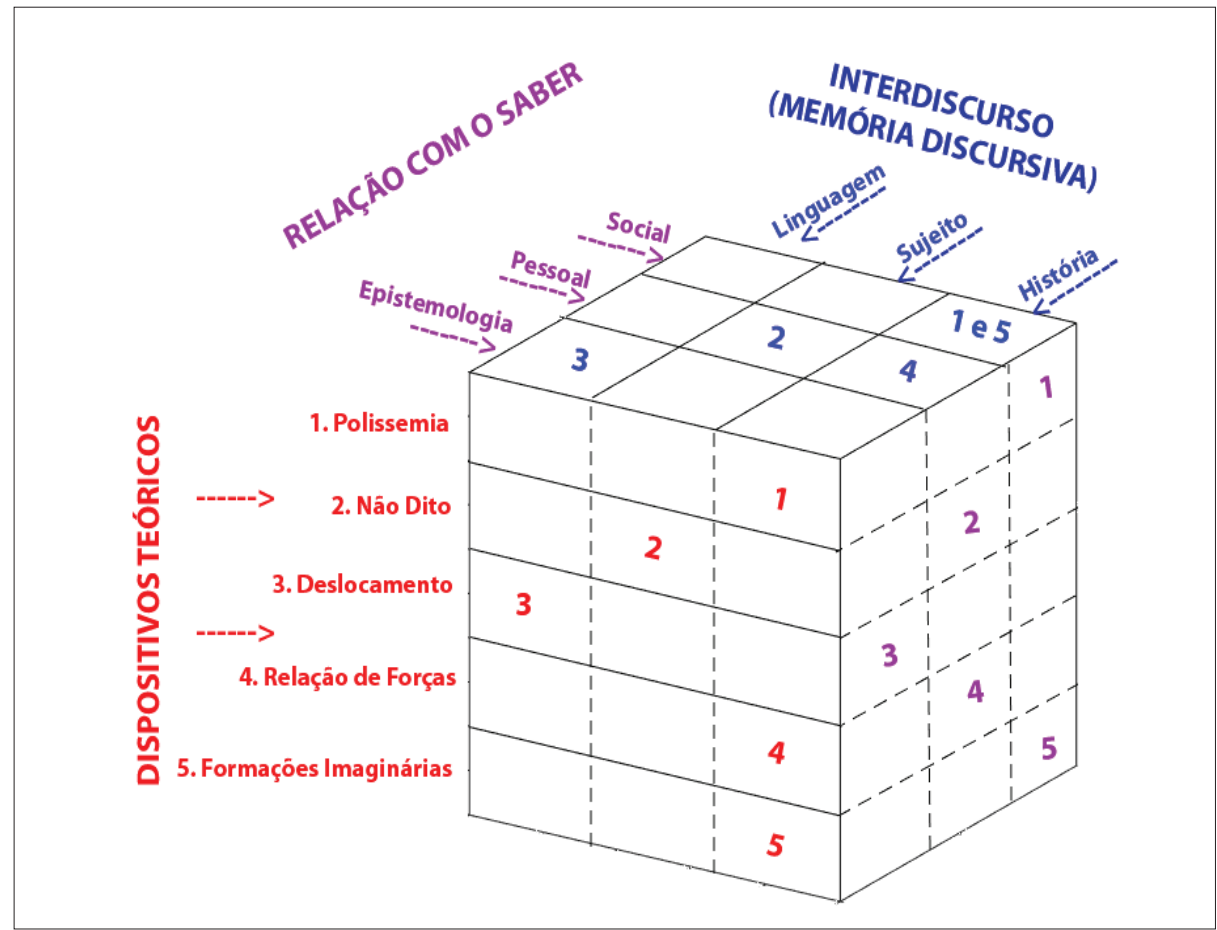

Fonte: Cazón (2016).

\subsection{GESTOS DE ANÁLISE}

Na imagem do cubo há os posicionamentos de cada análise, representados por um número, iniciando por "1". O mesmo número aparecerá em duas ou três faces diferentes, pois compreende a intersecção formada. É como se o número fosse ao interior do cubo até a intersecção.

Em cada análise haverá escrito, dentro de parênteses, o tempo dos minutos e segundos em que é possível ver o fato observado e que está sob análise.

\subsubsection{Entrecruzamento1: polissemia - história - social}

Recorte: Fragmentos entre os minutos 1:45 a 12:51 - Perguntas feitas para o pesquisador epara as pessoas do bairro: "o que é um cromossomo? Como ocorre uma síndrome? Se você soubesse que estaria esperando um filho com algum tipo de síndrome, como seria sua reação?”. Perguntas feitas para a mãe do garoto portador da Síndrome de Down.

Para explorar o tema anomalias cromossômicas, com enfoque para a Síndrome de Down, o grupo de alunos pesquisou em livros, revistas e na internet. Também assistiu às aulas de Biologia no colégio sobre os variados tipos de síndromes que estão ligadas às mutações cromossômicas, numerais ou estruturais. Com esse suporte os 
alunos elaboraram um roteiro de entrevista com perguntas que tratavam de conceitos sobre as síndromes (DNA, cromossomos, cariótipos, mutações, exames clínicos etc.) e perguntas de cunho pessoal. Essas perguntas foram feitas para pessoas do bairro (cabeleireira, dona de casa) e para o pesquisador em genética da universidade.

Ao longo da entrevista, o pesquisador respondeu que existe a possibilidade de pessoas com síndrome de Down constituírem família e reiterou a importância de inseri-las na sociedade, pois quanto mais cedo estiverem se socializando, maior é a tendência de desenvolverem habilidades e dependerem menos de outras pessoas nas atividades básicas do dia a dia.

Percebemos neste ponto, o encontro entre os pilares fundamentais que sustentam a relação com o saber: o sentido, a mobilização e a atividade. Explicando os acontecimentos, os alunos viram sentido na atividade que estavam realizando, por isso fizeram questionamentos para diferentes pessoas e se mobilizaram na busca de outras respostas. A curiosidade aqui estabelecida os mobilizou. Portanto, nossa tentativa foi compreender como se deu tal relação como saber entre os sujeitosalunos, o porquê da produção de sentido, de curiosidade etc. Acreditamos que se fez sentido é porque já refletiram anteriormente a respeito, então, supostamente, este fato se relacionou com outras experiências vivenciadas.

Lembrando que o desejo é o ponto que sustenta a mobilização. Os sujeitos que se colocaram em movimento pela busca de respostas tiveram como combustível o desejo por saber mais sobre o assunto. Ocorreu um investimento por parte dos alunos, que se colocam como recurso para fazer acontecer a atividade, pois sentiram desejo, atribuíram valor e, portanto, viram sentido naquilo.

Em um momento do documentário, os alunos perguntam para homens e mulheres de faixas etárias diferentes: "Se você soubesse que estaria esperando um filho com algum tipo de síndrome, como seria sua reação?”. Inserindo os depoimentos dessas pessoas expressando seus posicionamentos em relação à síndrome.

Observamos que os autores do documentário, ao selecionarem a pergunta, estão em busca de avaliar o julgamento das pessoas que nunca tiveram vivência com um indivíduo portador da síndrome. Alguns entrevistados responderam que tomariam um susto, que ficaria louca ou desesperada. Outros disseram que não teria problema e, um entrevistado de aparência jovem, afirmou que abortaria.

É possível observar que os alunos tentam construir um diálogo ao colocarem a fala do cientista e a fala das pessoas entrevistadas na rua e também polarizar as identidades de "cientista" e de "pessoa comum".

De um lado, o pesquisador que trabalha com ciência fala sobre o conhecimento científico, em específico da área de Biologia. De outro lado, os transeuntes, expõem a compreensão de mundo através de experiências próprias. O discurso das pessoas comuns, chamado de senso comum, é baseado em fontes de conhecimento como a tradição, a intuição e o bom-senso.

Com base no conceito de Relação como Saber, percebemos que, anteriormente, os alunos estavam em uma relação advinda de uma articulação do tipo epistêmica (conceitos sobre genética) e passam para uma articulação de valores sociais (preconceito), com o intuito de desconstruir a declaração de um entrevistado participante que disse abortar a criança, caso soubesse antecipadamente que seu filho seria um indivíduo portador de síndrome. 
Os sujeitos e os sentidos são constituídos nessa relação de paráfrase e polissemia. O momento de polissemia dá-se aqui, pois os autores, ao se depararem com o depoimento, buscam, criativamente, mostrar, através do discurso de outra pessoa, que não há necessidade de recorrer ao aborto. Então na parte final do documentário eles tentam construir argumentos fundamentados, através da experiência de vida de uma mãe, que tem um filho com Síndrome de Down. Apontando que "os sentidos e os sujeitos sempre podem ser outros. Depende de como são afetados pela língua, de como se inscrevem na história" (ORLANDI, 2012, p. 37).

Pelo que acompanhamos, um dos sujeitos conhecia essa mãe, ela fazia parte de sua família. Portanto, aqui há mais uma evidência de que a experiência de vida do sujeito está presente e o colocou em movimento, em prol de uma conscientização para que não aconteça a escolha pelo aborto.

A relação que o sujeito apresenta com o saber está na articulação social, pois nos parece que o impulso é justamente o preconceito. Na perspectiva da AD, situa na articulação histórica em relação à sua memória discursiva. Podemos inferir que o sujeito sabe que há muitos casos de famílias que têm filho com síndrome e que é possível ter uma vida completamente viável. Aqui o sujeito se faz presente, está inserido nessas relações que o incomodam de certa maneira, ou seja, está inserido na cultura e assume essa postura no contexto histórico-social. A partir dessa questão muito bem conduzida, é que vemos os alunos na função-autor, como aluno-autor.

A aproximação entre os dois campos teóricos evidencia que há uma relação indissociável entre sujeito, linguagem e história (conforme a $\mathrm{AD}$ ) e que um saber só tem sentido nas relações que supõe e produz com o mundo, consigo, com os outros.

\subsubsection{Entrecruzamento 2: não-dito - sujeito - pessoal}

Recorte: Fragmento 13:00 minutos - O final do documentário apresenta uma imagem de um bebê sorrindo, com características físicas de Síndrome de Down. Na imagem está escrito "21 de março - Dia Internacional da Síndrome de Down”.

No convívio com o grupo de alunos, soubemos que um dos sujeitos passou por um momento frágil de saúde. Este aluno teve um tipo de câncer na infância, necessitando de tratamento até a pré-adolescência, se curou, porém lida, ainda hoje, com outras fragilidades decorrentes. Certamente, o apelo pela conscientização sobre a Síndrome de Down tem raízes nessa experiência de vida, o que o mobilizou a esclarecer que devemos repensar sobre nossos preconceitos.

Apesar de não ter sido falado, anunciado ou narrado algo que fizesse menção à conscientização, entendemos que a imagem exposta está na forma do não-dito, pois fica subentendido que há a pretensão de conscientizar. Para a AD no discurso sempre existe a relação do que foi dito com o que não foi.

Outro ponto observado foi que os alunos fizeram escolhas em relação ao tema do documentário a ser desenvolvido. Anomalias cromossômicas e algumas síndromes era a única opção que envolvia a questão de doença/saúde. Julgamos que tal escolha está relacionada a esse sujeito (portador de câncer na infância). Sua condição pessoal o mobilizou.

Explicando nossa análise no cubo, o número 2 está no eixo dos dispositivos teóricos como o não-dito - a imagem do bebê com síndrome de 
Down acompanhado da frase do Dia Internacional da síndrome, que julgamos ter o intuito de conscientizar, mas está subentendido. Seguindo para o eixo do interdiscurso compreendemos que a experiência de vida do sujeito que passou por momentos de fragilidade de saúde o fez escolher o tema sobre síndromes. Uma vez que já deve ter passado por experiências de rejeição/vergonha, devido à perda dos cabelos, portanto sabe como é conviver aparentando estar doente ou com traços físicos que indicam alguma doença. Entendemos como sendo uma relação pessoal com o saber, pois o sujeito é singular, teve uma história pessoal, viveu momentos que nenhum ali viveu exatamente da mesma maneira. Assim, se engajou no comprometimento da atividade, levado pelo seu desejo e buscando inúmeras possibilidades de acrescentar colaboradores, recursos, técnicas, lugares, ideias, momentos em prol de um trabalho repleto de qualidade.

Embora, o sujeito, neste caso, possa ter sido o "propulsor" na atividade, o grupo em si se colocou em movimento numa mesma sintonia.

\subsubsection{Entrecruzamento 3: deslocamento - linguagem - epistêmico}

Conjuntura e recorte (fragmentos 0:45/1:15/4:50) - Solicitação de mais fontes de consulta e aprofundamento do tema (definição de cromossomo/ causadores das síndromes/alterações cromossômicas estruturais e sexuais).

$\mathrm{Na}$ produção do roteiro explicamos que havia uma gama de recursos que poderiam ser utilizados para efetuar a pesquisa: livros didáticos, revistas científicas (levamos dez exemplares sobre os temas escolhidos), sites de busca na internet etc. Compreendemos que apresentar possíveis meios para a pesquisa é, além de mostrar os recursos disponíveis, convidar os alunos a conhecerem outras fontes.

$\mathrm{O}$ aluno citado no recorte anterior, em especial, face à sua mobilização, curiosidade e interesse pelo tema, solicitou um material de nível mais técnico. Encaminhamos-lhe alguns artigos científicos que discutiam síndromes em animais. Seu desejo por aprender se mostrava recorrente, percebemos que em sala de aula apresentava certo domínio e profundidade na escrita sobre o tema. Percebemos que sua Relação com o Saber está voltada tanto para o pessoal quanto para o epistêmico, pois a pesquisa, o estudo o mobilizou. Uma vez que poderia ter se baseado nas anotações do caderno realizadas durante a aula sobre as anomalias cromossômicas ou no livro didático, mas foi além.

Pelo viés da AD, o repetível e o deslocamento acontecem simultaneamente, dependentes um do outro para acontecer. Outros alunos do mesmo grupo buscaram e pesquisaram nos meios que já conheciam, repetiram o que já sabiam fazer. É importante dizer que a repetição não denota trabalho inferior ou que esteja relacionada à preguiça de ir à busca de coisas novas. A repetição é tão importante quanto a descoberta do novo, pois a primeira é a matriz do sentido, não há sentido sem repetição. E a segunda é a fonte da linguagem, é a condição de existência do discurso.

São nos tempos marcados 0:45/1:15/4:50 do documentário que acontecem a apresentação mais profunda do tema. Devido à leitura desses artigos, o aluno incluiu explicações pertinentes acompanhadas do discurso do pesquisador logo em seguida. Observamos neste caso um momento de deslocamento, ou seja, de anseio epistêmico. O fato de buscar informações em um material, mais 
comumente, utilizado no ensino superior, aponta que houve transformação nas condições de produção do documentário. $\mathrm{O}$ aluno não se acomodou à reprodução das informações, sobretudo necessitou de mais elementos para se fundamentar, indo além de seu nível escolar.

Percebemos que nas primeiras ideias no roteiro inicial, este aluno apresentava dificuldade de entender, por exemplo, que, anomalias cromossômicas são mudanças que ocorrem no material genético, que podem acarretar em problemas severos, moderados ou irrelevantes nos indivíduos. E não necessariamente gerar monstruosidades como mencionado algumas vezes pelo aluno.

Fazendo um paralelo entre seu conhecimento prévio (anomalias genéticas geram monstruosidades) e o posterior, é possível observar um movimento discursivo de aprofundamento na linguagem, perceptível no discurso apresentado no documentário, por exemplo, que as síndromes são causadas por acréscimo de cromossomo ou perda de parte dele e que isto pode acontecer inclusive em plantas, essas seriam anomalias estruturais, mas também podem acontecer alterações cromossômicas sexuais.

$\mathrm{O}$ que fez o sujeito se colocar em movimento foi o desejo que tinha em saber mais sobre o assunto escolhido. Cremos que os questionamentos utilizados "O que tem desejo de saber?", "Se pudesse escolher um tema para pesquisar, qual seria?", despertaram a relação epistêmica desse sujeito com o saber. Aqui a Relação é com o conhecimento científico. Ele quis saber mais por sentir prazer em aprender.

Fato observado nos apoios que o sujeito utilizou para se apropriar de um saber que ainda não possuía: objetos (artigos, livros, revistas e internet), pessoas (entrevistado-pesquisador, mãe de um portador de síndrome, professora de Biologia, pesquisador deste estudo) e locais (casa do garoto Down, universidade e escola).

As relações com o saber epistêmico se equilibram entre o teórico e o prático, o concreto e o abstrato, o real e o imaginário. Para os sujeitos que produziram o documentário os significados de "aprender" têm uma relação com o local, com o momento, com o tempo, com o outro, com a história do sujeito, que tem relação com a história numa perspectiva mais ampla. Este sujeito epistêmico, que aprende, entra em um relacionamento, que é afetivo e manifesta sentimentos.

\subsubsection{Entrecruzamento 4: relação de forças - história - pessoal}

Conjuntura - Foi agendado com pesquisadores da universidade um momento para que houvesse uma conversa deles com os alunos, reforçando a aproximação escola-universidade e, na sequência, a gravação das entrevistas.

O imaginário dos alunos sobre universidade, pesquisadores, fazer ciência etc., se mostra, em geral, muito distante, quase que irreal. Acreditamos que o contato com a academia desmistificaria tal imagem desconstruindo estereótipos. Ao acompanhá-los até a universidade foi perceptível a ansiedade, o medo, a insegurança de alguns alunos, pois fariam uma entrevista com um pesquisador (cientista).

É possível inferir algumas possibilidades para o comportamento inseguro dos alunos. Primeiro, que todo o contexto, a conversa, o levantamento de dúvidas, a entrevista, a gravação, o próprio local (a universidade) eram uma novidade. Segundo, que a imagem de "cientista" presente no histórico-imaginário deles certamente se assemelhava à caricatura de um "gênio", ou um ser não comum. 
Antes de sairmos do colégio, nos reunimos para os últimos ajustes: quem ficaria responsável por entrevistar, outro para gravar, para ficar na produção técnica do vídeo, para fazer anotações diversas etc. Dividimos os papéis, lembrando que, por ser um trabalho coletivo, todos eram responsáveis pelo todo.

A análise que fazemos neste entrecruzamento se refere à tomada de posição dos sujeitos ao fazerem a entrevista. Ainda que apresentando ansiedade, agitação, nervosismo, por ter que fazer a entrevista em frente aos outros colegas de sala de aula, conduzir uma entrevista com um profissional da área de pesquisa sob câmeras filmadoras, os sujeitos assumiram a posição de entrevistador e colocaram o cientista no lugar de entrevistado. Aqui os sujeitos "deixaram" de ser alunos e falaram em outra posição, assumindo a responsabilidade que o papel de entrevistador sustenta. Para estes sujeitos, a entrevista estava em suas mãos e era necessário pensar nos detalhes mais minuciosos para que tudo fosse bem executado. Cabe considerar aqui as condições de produção que fizeram parte deste momento.

Retomando a AD, "as condições de produção implicam o que é material (a língua sujeita ao equívoco e a historicidade), o que é constitucional (a formação social, em sua ordem) e o mecanismo imaginário" (ORLANDI, 2012, p. 40). O sujeito inserido em uma conjuntura sócio-histórica (eixo do interdiscurso, articulação da história) produz imagens dos sujeitos e dos objetos do discurso.

A troca entre locutor e interlocutor é, pois, um jogo imaginário. Este jogo pode ficar mais complexo se considerarmos a antecipação, ou seja, a imagem projetada que o locutor faz da imagem que o interlocutor faz dele e "a imagem que o interlocutor faz da imagem que ele faz do objeto do discurso" (ORLANDI, 2012 , p. 40). Tais formações imaginárias começaram a invadir a mente do aluno desde quando ele soube que faria a entrevista.

Interpretamos esta conjuntura como sendo de relação de forças (eixo y), "pois o lugar a partir do qual fala o sujeito é constitutivo do que ele diz" (ORLANDI, 2012 , p. 39). Se ele se posiciona como entrevistador, é desta posição que ele parte para o discurso. Como a sociedade é constituída por relações de hierarquia, onde diferentes lugares sustentam diferentes poderes, são, portanto, as relações de força que valem no diálogo. Desta forma, entendemos que a memória discursiva dos sujeitos, conscientemente ou não, traz da história (eixo x), da sociedade, essa maneira de compreender as relações de força, relações hierarquizadas estabelecidas.

Observamos algumas conversas entre os alunos e o pesquisador sobre aptidões, vontades, desejos que tinham sobre as áreas de estudo e trabalho após o término do ensino médio. Coincidentemente, muitos alunos relataram se interessar por áreas como enfermagem, biologia, química, daí compreendemos que a mobilização em se encorajarem para entrevistar um pesquisador remetia às vontades pessoais. Esta predisposição não esteve apenas atrelada às relações de força, o que faz girar o eixo de locomoção dos sujeitos tem suas raízes nos desejos, nas vontades e nos sonhos de cada um. Desejos pessoais.

Portanto, encaramos esta condição da entrevista e toda sua conjuntura como sendo uma relação identitária dos alunos com o saber, pois o sentido produzido no sujeito leva em consideração sua história, desejos e expectativas, a imagem que tem de si (aluno, sonhador, idealista, entrevistador) e a imagem que quer projetar de si no outro (futuro profissional da área de ciências, entrevistado). Neste caso, o outro 
pode ser tanto o sujeito entrevistado, quanto o "cientista" idealizado que está no imaginário que cada um sustenta dentro de si. A relação identitária com o saber nada mais é do que colocar em evidência a construção de si mesmo.

\subsubsection{Entrecruzamento 5: formações imaginárias - história - social}

Conjuntura e recorte - Os alunos ao longo da entrevista com o pesquisador da área de genética se condicionaram a usar a norma culta da linguagem, a se comportarem de modo que transparecesse uma boa condução discursiva. Ex: uso de expressões como "longa sequência", "contém vários genes", "indivíduo portador", "como ocorre uma síndrome".

Observamos nesta conjuntura o lugar e as posições dos sujeitos. O lugar ocupado pelos sujeitos empíricos está na ordem de jovens, moradores de um bairro de Curitiba, alunos de um colégio (aprendizes), amadores na produção do documentário, sujeitos hierarquizados em uma instituição (são alunos que aprendem e são ensinados por professores num relacionamento hierarquizado). Este lugar de aluno também se faz presente ao entrevistar o pesquisador, que é especialista na área em que os alunos desejam aprender. Os sujeitos-alunos sabem dos papéis (do outro e de si) que ocupam na sociedade.

Já as posições dos sujeitos abarcam as projeções feitas em determinados momentos. Por exemplo, os alunos necessitam entrar numa interlocução com o pesquisador (projetado como alguém que possui um grau de conhecimento mais elevado sobre o tema em questão). Assim, não são os alunos (sujeitos físicos), nem seus lugares empíricos que funcionam no discurso e sim as imagens resultantes de projeções. São as posições que significam no discurso.

Neste caso, as projeções feitas pelos alunos são a de que o "cientista", para ocupar o cargo de "homem da ciência", dedicou anos exclusivamente para estudos de alto nível, por isso seu jeito de pensar, falar, se comportar, carrega traços característicos da norma culta da língua, da forma de expor o pensamento científico seguindo uma linha de raciocínio apropriada, etc. Tal imagem foi construída pelo que viram e ouviram, são sujeitos inscritos na história (eixo do interdiscurso) e na sociedade. Experiências que estão presentes em suas memórias discursivas.

Não somente durante a entrevista, mas, em todo o documentário os estudantes se esforçaram em usar a norma culta da língua portuguesa, por se portarem de modo que passassem a impressão de sujeitos que falam, pensam e se comportam num nível semelhante ao contexto do entrevistado, do "cientista".

Destacamos, nesse caso, a formação imaginária (dispositivos teóricos), ou seja, a projeção feita pelos alunos da imagem idealizada do cientista, que trazem na memória: uma articulação histórica dessa projeção. A Relação com o saber estabelecida se articula com o social, pois os sujeitos estão num processo de humanização. Os alunos se esforçaram, prestaram atenção, buscaram aperfeiçoar as aptidões no momento em que aconteceu a "prova de fogo", a entrevista. O que os colocou em movimento, isto é, o que os mobilizou, foi justamente essa busca por aprender o assunto desejado com o sujeito que "domina" o assunto (conforme a projeção estabelecida nas formações imaginárias e da memória que trazem da história). 


\section{CONSIDERACְÕES FINAIS}

A matéria-prima desta pesquisa é o sujeito, o discurso dos sujeitos-alunos, buscando, por meio de uma atividade nova para eles, priorizar o conceito de mobilização. Desta forma, adotamos como estratégia inicial perguntas que permitissem ao aluno escolher o que lhe despertaria prazer em pesquisar. Para isso, promovemos a aproximação de dois campos teóricos para compreender as relações que os sujeitos mantiveram com o saber, em suas diversas articulações discursivas.

A escolha por produzir um recurso audiovisual como ferramenta para a investigação pode parecer uma imposição ao aluno, mas temos outros sentidos para essa questão. Primeiramente, encaramos o documentário como um desafio para os alunos, pois muitos nunca haviam elaborado algo parecido, assim acreditamos que a dificuldade de execução e a finalização do todo exigiriam empenho dos estudantes. De fato, se dedicar suficientemente seria uma condição obrigatória e assim, consequentemente, um modo de compreender possíveis sinais de mobilização.

O cerne da investigação não está especificamente no gênero documentário em si, mas ancorado no objetivo deste trabalho, o de compreender quais as relações que os alunos apresentam com o saber na atividade de produção de documentário científico no ensino de Biologia. Para tal compreensão, interpretamos como essencial a presença da linguagem, que é opaca e constituída de materialidade simbólica própria e significativa, nos permitindo analisar os sentidos produzidos.

Esta atividade mostrou que deixar o aluno escolher o que deseja aprender e a posição que escolhe estar, o afasta da ideia de que há um jeito "certo" ou "errado" de se fazer uma atividade, abafando, desta forma, a ideia de estar sob julgamento. Possibilitar a autonomia do aluno, nesses pequenos detalhes é, sobretudo, proporcionar o reconhecimento de suas ideias e de seus pensamentos em relação ao que se estuda.

Abrir este caminho para o aluno é também permitir que ele mesmo trace ou entrecruze o caminho passando por alguns pontos, nos quais ele é quem decide se para, se continua, se toma outro rumo. Poderíamos dizer que é "experimentando que se aprende". Pois, experimentar ofusca a necessidade de acerto ou erro. As relações com o saber são também relações com o experimentar. A afirmação de Charlot de que o aluno só aprende aquilo que já sabe, cabe muito bem aqui, nessa questão da experiência. Conforme observamos, a importância de colocar o aluno em novas experiências como protagonista da atividade (de sua atividade) ou em experiências já vividas, porém em um contexto específico, é posicionar o aluno numa relação com o saber em que sua memória seja acionada e que suas já-experiências sejam fortalecidas e construídas com outras, com aquele outro. Outra coisa, outro sujeito, outro momento, outro questionamento, outra dúvida, outro não ou sim. $\mathrm{O}$ fato de estar em experiência diminui o significado de sim ou de não, de certo ou errado, faz referência ao que já sabe sobre o outro e aprende com o outro.

Nem mesmo o aluno tem certeza se sabe ser um entrevistador, escritor, roteirista, filmador etc. É a partir dessa experiência que descobre sobre si. Quando falamos em experiência, nos referimos ao pessoal. Se a experiência passou por mim, tem uma validade, mas se é procedente do outro é uma não-experiência. Para ser válida, tem que passar pelo sujeito, acontecer com o sujeito. Daí a importância 
de ser autor. Por isso acreditamos que quanto mais um indivíduo experimenta os sabores das coisas, mais as ideias dele sobre si, sobre o outro e sobre o mundo podem se transformar. Somente a partir do experimentar é que o indivíduo saberá se gosta mesmo de algo que suspeitava gostar, ou se passa a gostar de algo que nem mesmo suspeitava gostar.

Podemos considerar que a experiência tida pelos alunos-documentaristas os coloca perante outro documentário em uma relação diferente, posicionando-os como um avaliador, um roteirista, um entrevistador etc. São as já-experiências que significam. Um documentário será visto de outras maneiras.

Uma experiência vivida pelos alunos e que chamou atenção foi a postura deles aos falarem em outra posição, na de entrevistador, na de escritor, na de cientista, na de documentarista. São várias as possibilidades a começar pelo ambiente. Diferentemente do ambiente "sala de aula" ou "pátio do colégio", o ambiente universitário e a figura do "pesquisador universitário" trouxeram para a ocasião o sentimento de tensão. É a prova de fogo na entrevista. A mudança de ambiente pode trazer uma contribuição para a relação do aluno com o saber, ainda mais quando lembramos que o desejo de muitos alunos é, futuramente, se ver também na mesma posição do entrevistado. Diríamos que a posição do outro pode mobilizar o sujeito.

Avaliamos que somente pudemos aproximar os dois campos teóricos, naquilo que ambos interpretam, o sujeito, sabendo também onde se encontram seus limites. Não há aqui, portanto, uma mescla e sim uma aproximação na qual se pode permear os sentidos produzidos e aflorar as subjetividades, uma vez que as suposições levantadas na análise estão fundamentadas na "auscultação" do sujeito, no convívio diário.

Consideramos um ponto importante: a relação mais próxima entre professor-aluno. As análises feitas através do cubo só puderam ser realizadas devido a essa aproximação. O relacionamento que exprime afeto constrói, imperceptivelmente, o estado de compromisso, que pode levar à mobilização. Se a questão de comprometimento é instaurada, o respeito é inevitável. E assim gera-se um circuito de trabalho no qual professor e aluno são beneficiados. Percebemos que afetividade e respeito fazem o aluno desabrochar, pois o aluno confia e aprende com o professor. E vice-versa.

\section{AGRADECIMENTO}

Agradecemos à CAPES pelo apoio financeiro.

\section{REFERÊNCIAS}

ANOMALIAS cromossômicas: um olhar sobre a Síndrome de Down. Disponível em: <https://

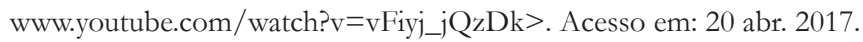

CAZÓN, Heron O.A. As relações dos alunos com o saber na atividade de produção de documentário científico no ensino de biologia. Dissertação - Programa de Pós Graduação em Educação, Universidade Federal do Paraná, 2016. 
CHARLOT, B. Da relação com o saber às práticas educativas. São Paulo: Cortez, 288 p. Coleção docência em formação: saberes pedagógicos. 2013.

CHARLOT, B. Os jovens e o saber: Perspectivas mundiais. Porto Alegre: Artmed, 2001.

CHARLOT, B. Da relação com o saber: elementos para uma teoria. Porto Alegre: Artmed, 2000.

NICHOLS, B. Introdução ao documentário. $5^{\text {a }}$ ed. Campinas: Papirus, 2012.

ORLANDI, E. P. Análise de discurso: princípios e procedimentos. $10^{\mathrm{a}}$ ed. Campinas: Pontes, 2012.

ORLANDI, E. P. Discurso e Leitura. $8^{a}$ ed., São Paulo: Cortez, 2008.

RAMOS, F. P. Mas afinal... o que é mesmo um documentário? São Paulo: Senac São Paulo, $2^{\mathrm{a}}$ ed., 2013.

REZENDE, L. A. Microfísica do documentário: ensaio sobre criação e ontologia do documentário. Rio de Janeiro: Beco do Azougue, 2013.

\section{NOTAS}

${ }^{1}$ Entendemos por "recorte", um ou mais fragmentos do documentário analisado. Anotamos os fragmentos em função do tempo decorrido desde o início do vídeo.

2 Entendemos por "conjuntura", a combinação de acontecimentos ou circunstâncias num dado momento. Acompanhando os estudantes na trajetória de construção do audiovisual, observamos e ouvimos os entremeios deste trabalho. Assim, tomamos tais momentos particulares, como elemento de investigação os quais fazem parte de todo o processo, portanto também são aqui analisados.

\section{Submetido em 09/05/2017}

Aprovado em 15/02/2018

\section{Contato:}

Heron Omar Arraya Cazón

Rua Anita Ribas, 199

CEP 82.520-610 - Curitiba, PR - Brasil 